OPEN ACCESS

Edited by:

Mariana Padron,

UMR8222 Laboratoire

d'Ecogéochimie des Environnements

Benthiques (LECOB), France

Reviewed by:

Johann Bell,

University of Wollongong, Australia

Simon Nicol,

University of Canberra, Australia

Reniel Cabral,

University of California,

Santa Barbara, United States

${ }^{*}$ Correspondence:

Alexander Tilley

alex.tilley@gmail.com

Specialty section:

This article was submitted to

Marine Conservation

and Sustainability,

a section of the journal

Frontiers in Marine Science

Received: 15 December 2018

Accepted: 18 July 2019

Published: 13 August 2019

Citation:

Tilley A, Wilkinson SP, Kolding J, López-Angarita J, Pereira $M$ and

Mills DJ (2019) Nearshore Fish Aggregating Devices Show Positive Outcomes for Sustainable Fisheries

Development in Timor-Leste.

Front. Mar. Sci. 6:487.

doi: 10.3389/fmars.2019.00487

\section{Nearshore Fish Aggregating Devices Show Positive Outcomes for Sustainable Fisheries Development in Timor-Leste}

\author{
Alexander Tilley ${ }^{1,2 *}$, Shaun P. Wilkinson ${ }^{3}$, Jeppe Kolding ${ }^{4}$, Juliana López-Angarita ${ }^{5}$, \\ Mario Pereira' ${ }^{1}$ and David J. Mills ${ }^{2,6}$

\begin{abstract}
${ }^{1}$ WorldFish (Timor-Leste), Dili, Timor-Leste, ${ }^{2}$ WorldFish (Malaysia), Penang, Malaysia, ${ }^{3}$ School of Biological Sciences, Victoria University of Wellington, Wellington, New Zealand, ${ }^{4}$ Department of Biological Sciences, University of Bergen, Bergen, Norway, ${ }^{5}$ Talking Oceans Foundation, Bogotá, Colombia, ${ }^{6}$ Australian Research Council Centre of Excellence
\end{abstract} \\ for Coral Reef Studies, James Cook University, Townsville, QLD, Australia
}

Capture fisheries in small island developing states (SIDS) have the capacity to increase access to vital micronutrient-rich food to tackle malnutrition, but when fishers are restricted to nearshore habitats by limited capacity (boats, engines, fishing gear), fisheries production can be low. This is the case of coastal Timor-Leste, where some of the world's most diverse coral reefs are juxtaposed with one of the world's most undernourished populations. In these settings, interventions that have successfully improved livelihoods from fishing and reduced threats to biodiversity are rare. Elsewhere in the Pacific, nearshore anchored fish aggregating devices (FADs) have shown success in improving catch rates by making pelagic stocks more accessible to small-scale fishers. Here we test the effects of FADs at increasing capture fish production, by deploying eight experimental FADs at four sites around the country and recording catch and effort data from FAD and non-FAD fishing trips. We assess the effects of FADs on catch rates and catch assemblage and the rate of $100 \%$ return on investment (Rol). The average longevity of FADs was 11 months. Results show a significant positive effect of FADs on catch rates when controlling for random site variation, with FADs paying for themselves in $\sim 5$ months or less at three out of four sites. Across all sites and fishing types, 63 species were identified, but FAD catches significantly reduced overall assemblage diversity, with three species (Sardinella spp., Decapterus macarellus, Rastrelliger brachysoma) representing $96 \%$ of the catch. Despite the relatively short longevity of FADs deployed in Timor-Leste, the fast Rol seen at most sites indicates that FADs are effective in providing livelihood benefits in certain locations. Catch rates were highest where fishers were specialized, invested in FAD fishing, and formed catch sharing groups with access rights to specific FADs. National level investment into a FAD programme by the government could realistically increase overall fish production in the country, thereby improving availability of micronutrient rich fish to combat malnutrition. A deployment program should be coupled with capacity building around group formation and defining access rights to ensure equitable community benefits. 


\section{INTRODUCTION}

People living in small island developing states (SIDS) of AsiaPacific gain disproportionate livelihood and nutrition benefits from nearshore marine habitats (Connell, 2013). Small-scale fisheries (SSF) in these SIDS predominantly rely on coral reef habitats that are increasingly under threat from diverse drivers (Hughes et al., 2003; Pandolfi, 2003; Bellwood et al., 2004), diminishing their ecological function and potentially affecting the well-being of the millions of people with reef-dependent livelihoods (Teh et al., 2013). Localized fishing and coastal development are pervasive drivers of reef degradation (Mora et al., 2011; Hughes et al., 2017), and with increasing climate variability comes greater vulnerability of fishers (Sainsbury et al., 2018). At current rates of population growth, global food production must increase by $60 \%$ by 2050 to feed the world (FAO, 2009) yet in SIDS, alternative sources of food and livelihoods are often constrained by physical geography and natural resources, human and financial resources, infrastructure, and viable markets (Feeny and McGillivray, 2010; Campbell et al., 2016). Less than a third of Pacific countries will be able to meet per capita fish consumption demand in 2030 based on current SSF practices (Bell et al., 2009). As such, projections of the food deficit and the required increases in yield underpin national and regional development strategies, but effective, affordable and scalable governance solutions with minimal environmental degradation, remain elusive.

Anchored, nearshore fish aggregating devices (FADs) are suggested as a practical and efficient means of improving local food security and reducing pressure on reefs by making oceanic fish more available and accessible to artisanal fishers, and thereby providing an immediate improvement to food security (Bell et al., 2009, 2015b; Sharp, 2011). There is convincing evidence that since their adoption in the Pacific in the late 1970s, FADs have in many instances substantially increased SSF catch rates (Matsumoto et al., 1981; Désurmont and Chapman, 2000; Dempster and Taquet, 2004; Sharp, 2011). As such many Pacific nations have integrated the deployment of FADs into their national fisheries action plans and policy (Sharp, 2011; Campbell et al., 2016). Research into financial cost-benefit analysis of FAD deployments, even in the artisanal sector, is mostly restricted to FADs anchored far offshore ( $>12$ nautical miles) targeting tuna, with reported return rates of between 40 and 312\% (Sims, 1988; Detolle et al., 1998; Sharp, 2011; Guyader et al., 2013). Far fewer studies evaluate returns on investments of nearshore FADs, within three nautical miles of the coast.

In Pacific SIDS, fishing provides the major source of animal protein (Bell et al., 2009), whereas, in Timor-Leste, the fisheries sector is considered to be functioning well below its potential (Alonso Población, 2013; Mills et al., 2013). Since 2002, an independent, post-conflict Timor-Leste has made rapid development progress but faces significant challenges in alleviating poverty and food insecurity. Ranked 10th on the Global Hunger Index, Timor-Leste has the 2nd highest prevalence of childhood stunting in the world (low height for age), affecting more than 50\% of children under five (von Grebmer et al., 2018). Recent consumption data suggest a national average fish consumption of only $6.1 \mathrm{~kg}$ per person per annum (AMSAT International, 2011), well below neighboring Indonesia $(27 \mathrm{~kg}$ ), or the global average of $20.5 \mathrm{~kg}$ (FAO, 2018). Fisheries do play an important role in nutrition and livelihoods for coastal dwellers in Timor-Leste (Mills et al., 2017), who consume almost three times more fish than the national average (AMSAT International, 2011). Yet, a lack of economic incentives to invest in the sector due to poor infrastructure and low economic returns (Hartmann, 2010) jeopardizes the stated development goal of doubling capture fisheries productivity (an increase of 6,500 t) by 2020 (GOTL, 2011).

Proponents of nearshore FAD deployment programs typically advocate for their use in providing artisanal fishers with access to high productivity, high-value tuna fisheries (Bell et al., 2009, 2018). In Timor-Leste, FADs primarily increase access to stocks of small pelagic fish, promoting the use of a high productivity resource (rapid growth, short lifespans, and high mortality rates) better adapted for supporting sustainable fisheries (Dalzell, 1993). Research deployments of FADs in Timor-Leste only started in 2013. Prior to that, a few communities constructed and deployed traditional FADs. A near-complete absence of current data on fisheries yields and income means that quantitative estimates of the impacts of FAD deployment have previously been impossible for Timor-Leste. The aim of this paper is to explore if a national inshore FAD program can contribute to food and nutrition security in Timor-Leste. We use catch data, vessel tracks and interview data from communities participating in a pilot FAD programme by Timor-Leste's Ministry of Agriculture and Fisheries (MAF) and WorldFish to evaluate: (1) How do FADs affect SSF catch and effort rates and catch assemblages using existing and augmented gears?; (2) What is the economic rate of return on investment of FAD deployments?; and (3) What are the key opportunities and constraints to scaling FAD deployment?

\section{MATERIALS AND METHODS}

\section{Study Sites and FAD Deployment}

For this study, we utilize fishing data from four communities where eight FADs were deployed by WorldFish and MAF between September 2016 and July 2017 (Table 1). The evolved design and deployment methods of the FADs follow those detailed in Mills and Tilley (2017).

The four community sites represent the three ecologically distinct zones of Timor-Leste: Biacou and Vemasse are located on the dry north coast of the mainland with very narrow and steep reef shelf, Adarai on the more exposed south coast with a long gradual continental shelf slope, and Adara on the more sheltered west coast of Atauro Island with a steep reef dropoff to $>4000 \mathrm{~m}$ depth (Figure 1).

\section{Fisheries Characterisation and Catch Documentation}

To characterize the fisheries in each site, informal interviews and discussions were conducted in study communities during FAD construction and deployment processes, and by data collectors at landing sites. Information on gear types in use, diel and seasonal 
TABLE 1 | Deployment depth and longevity of artisanal nearshore fish aggregating devices at four community fishing sites in Timor-Leste.

\begin{tabular}{|c|c|c|c|c|c|}
\hline Site & Depth (m) & Date deployed & Date lost & Duration (months) & Distance from shore $(\mathbf{k m})$ \\
\hline \multirow[t]{2}{*}{ Adara } & 170 & 1-Sep-16 & Mar-17 & 7 & 0.57 \\
\hline & 158 & 29-Jul-17 & Apr-18 & 11 & 0.45 \\
\hline \multirow[t]{3}{*}{ Vemasse } & 340 & 03-Mar-17 & Sep-17 & 6 & 2.77 \\
\hline & 260 & 03-Mar-17 & Mar-18 & 12 & 2.35 \\
\hline & 250 & 03-Mar-17 & Mar-18 & 12 & 1.85 \\
\hline \multirow[t]{2}{*}{ Adarai } & 65 & 27-Apr-17 & - & $18+$ & 2.66 \\
\hline & 65 & 27-Apr-17 & - & $18+$ & 3.62 \\
\hline \multirow[t]{2}{*}{ Biacou } & 100 & 12-May-17 & Apr-18 & 11 & 1.96 \\
\hline & & & Average & $11.9 \pm 4.4$ & 2.03 \\
\hline
\end{tabular}

Where no "Date lost" listed, FADs are still in place. Gray shading separates sites.

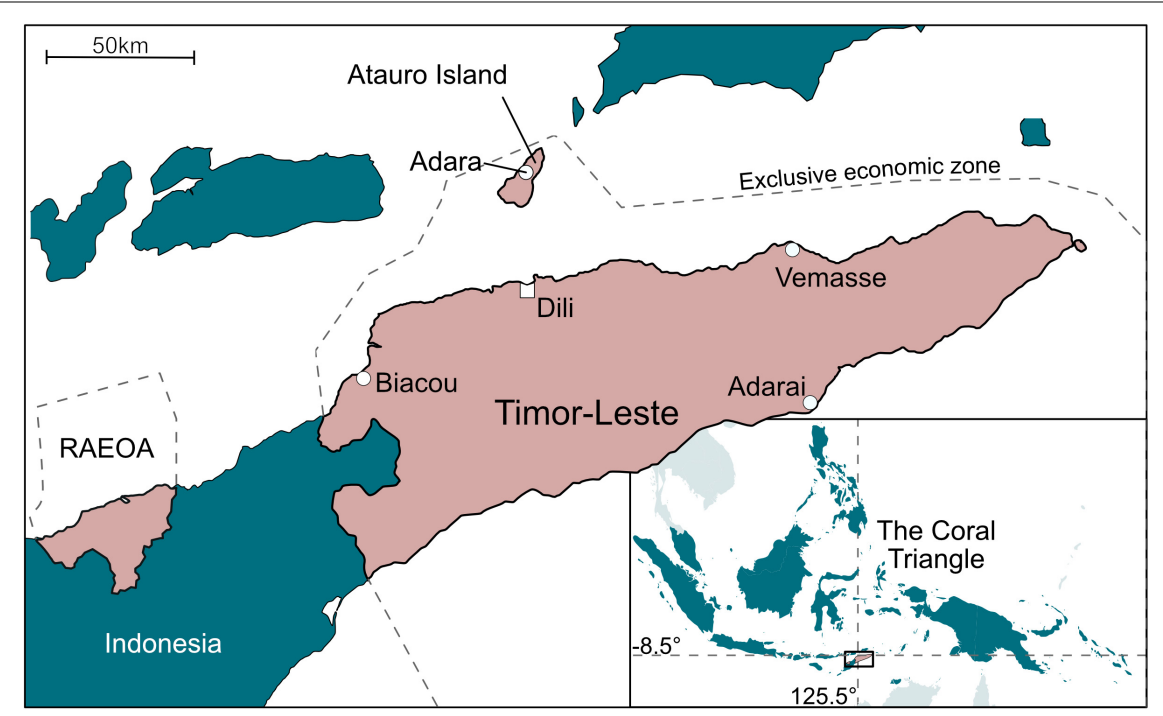

FIGURE 1 | Location of Timor-Leste with the Coral Triangle (inset), and the location of four study sites for testing nearshore FAD deployments. Dotted lines represent the Exclusive Economic Zone of Timor-Leste. The RAEOA is the Special Administrative Region of Oecusse-Ambeno. (Adapted from Tilley et al., 2019. Map created using a vector layer adapted from FreeVectorMaps.com@Striped Candy LLC.)

timing of fishing, fishing frequency, and access and ownership arrangements of fishing grounds and FADs were collected and used to interpret fish landings data.

Landings data were gathered by data collectors in fishing communities between September 2016 and September 2018. To balance the study design and control for year to year variations in abundance and/or catch rates, one year of data between April 2017 and March 2018 was used for analyses of FAD effects on catch rates.

A community member at each of the landing sites was trained in fish identification and the use of a tablet-based survey form developed using the mobile survey software suite KoBoToolbox ${ }^{1}$ for Android devices. Data entered on the tablet was uploaded to a central online database using KoboToolbox via a $3 \mathrm{G}$ connection. Only the catches of fishers based at each village site were recorded at the landing site associated with that village. We also recorded fishing gear, fishing location, number of fishers per boat, and the total numbers of boats out fishing on a given day (absolute effort).

${ }^{1}$ www.kobotoolbox.org
Monitoring was carried out daily where possible, at the time of day when most fishing boats returned to shore. Data collectors recorded the start time and end time of the trip, the gear used, the number of fishers on board, and the boat type. The habitat where fishing took place (reef, FAD, deep, mangrove, and beach) was recorded and was used to categorize trips to compare catch rates. Given the focus on comparing reef and FAD catch rates, in some comparisons deep, mangrove and beach catches were grouped as "other." The catch was quantified by the calculated weight and number of fish species present, the intended purpose of the catch (for food, sale, or both), and the current market price of each species (fisher's estimate).

\section{Effort and Boat Activity Estimation}

In this study, we use raw catch per unit effort (CPUE) to compare catch rates of different habitats across the different sites. Raw CPUE is simply the total catch divided by the sum of an observable measure of effort associated with the catch (Maunder et al., 2006). We standardize effort into the unit of fisher-hours 
on each fishing trip, calculated as the trip duration in hours multiplied by the number of fishers onboard. The complexity of more robust CPUE standardization of multiple gears in tropical, multiple habitat, mixed species fisheries make it impractical in a livelihoods context.

In February 2018, solar-powered vessel tracking systems (VTS) developed by Pelagic Data Systems Inc., were installed on 50 boats across the four sites (Adara, $N=5$; Vemasse, $N=15$; Adarai, $N=15$; Biacou, $N=15$ ) to gather continuous boat location information at a frequency of 1 position every $10 \mathrm{~s}$. The high-resolution tracks from these VTS from February to December 2018 enabled accurate quantification of fishing trip frequency and duration from which site-specific vessel activity coefficients (VAC) were derived, under the assumption that total monthly fishing effort does not change significantly within the year.

\section{Total Production Estimation by Site}

To estimate the total monthly catch for vessel-based SSF in each of the four sites, we combined observed landings data with VAC for paddle canoes and motor boats derived from VTS, and vessel census data from the Timor-Leste's MAF. The monthly catch (in tonnes; $C$ ) per site was calculated as:

$$
C=\sum_{b} C P U E_{b} \times V A C_{b} \times N_{b} \times 0.001
$$

where $b$ refers to the boat type (canoe or motor-powered), CPUE is the monthly catch per unit effort in $\mathrm{kg}$ per hour, VAC is the average total fishing hours per month per vessel, $N$ is the total number of active boats, and 0.001 converts the value from $\mathrm{kg}$ to tonnes. It is difficult to estimate the contribution of shorebased fishing to the total national catch since no census data are currently available for this fishing mode. However, shore-based fishing trips represented a minor proportion of trips recorded $(\sim 4 \%)$, and the CPUE was substantially lower than the boatbased trips on average (data not shown), therefore we elected to restrict our analysis to boat- and canoe-based fishing only.

\section{Effects of FADs on Catch Rates}

To estimate the effects of FAD presence on catch rates, effort, and trip success during the deployment period generalized linear mixed models were fitted to explain the observed fishery production results. Three response variables were analyzed: CPUE in kg per fisher-hour (rounded to the nearest integer and modeled as a Poisson random variable), CPUE in number of fish per fisher-hour (also modeled using a Poisson distribution), and trip success rate (the proportion of trips with non-zero catch; modeled as a binomial response). CPUE values were modeled as Poisson-distributed variables in order to account for leftcensoring in the data (on average $13 \%$ of the trips were recorded with no catch). For each analysis, the habitat type was included as a fixed effect (three levels; FAD, reef, or other) and site as a random factor (four levels). Temporal effects were not tested due to a lack of seasonal replication over time. Gear types were pooled due to insufficient replication and balance to account for the preferential use of certain gear types at certain habitats (for example, the preferential use of spear guns on reefs and seine nets only deployed on FADs). The final model equation is thus defined as:

$$
y \sim X \beta+Z u+\varepsilon
$$

where $y$ is the vector of production values (kg per hour, no. of fish per hour, or success rate), $X$ is the matrix of predictor variables, $\beta$ is the fixed-effect regression coefficients (habitat type), $Z$ is the design matrix for the random effects (site), $u$ is the vector of random effects, and $\varepsilon$ is the vector of residuals. Plots of residuals versus fitted values and normal quantiles were inspected for valid error distributions and variance homoscedasticity. Production analyses were carried out in the $\mathrm{R}$ environment ( $\mathrm{R}$ Core Team, 2018) using the packages lme4 (Bates et al., 2015) and effects (Fox, 2003).

\section{Cost-Benefit Analysis of Nearshore FADs}

A site specific rate of $100 \%$ return on investment in days (RoI) is calculated based on the catch dividend of the FAD, not the total catch of the FAD. The multiplication of Price of fish $(\$ / \mathrm{kg})$ by the change in catch rates between FAD and non-FAD fishing $[\triangle C P U E$ in $\mathrm{kg} /($ fisher $\times$ hour)], returns the change in revenue per unit effort. $S$ is the proportion of catch sold; $V A C_{\text {day }}$ (average total hours fishing per boat per day) and $N$ (total number of boats), are site specific values of effort; and $F$ is the site specific frequency of FAD trips as a proportion of total trips (adapted from Sharp, 2012). The relatively short longevity of FADs negated the need for the inclusion of an annual discount rate to account for inflation.

$$
R o I=\frac{\text { Investment }}{\left(\left(\left(V A C_{\text {day }} \times N\right) \times F\right) \times((\Delta C P U E \times \text { Price }) \times S)\right)}
$$

By basing the calculation of $R o I$ only on the proportion of fish sold, our estimates are inherently conservative, given we are placing no value on fish caught for consumption. In reality, any increase in production from FADs would also provide significant food and nutrition security value at a household level. The Price of fish $(\$ / \mathrm{kg})$ as sold by fishers was collected throughout the landings survey sampling period and the mean sale price from these data was used to estimate the difference in hypothetical revenue between FAD and non-FAD fishing. There were no discernible differences between mean prices per species across time, so a cumulative mean was used ${ }^{2}$.

\section{Catch Assemblages and Species Diversity}

Species were identified by trained data collectors using a list of 130 known local species with photos. Unknown species were listed as such and submitted along with a photograph taken of the species. A further 36 species were added to the species list in this

${ }^{2}$ The demand for fish is still low in Timor-Leste, even in urban centers. Large pelagic fish do not sell well for reasons of lack of capital, lack of refrigeration, no export market and only limited local cold supply chains. The most popular species are those that are small and dry well (sardines, scads, and mackerels), but all species have very similar market values with small price fluctuations based on abundance than on species (large catches sell for cheaper so that fishers can offload it all) (López-Angarita et al., 2019). 
way, using common and local names, or to class and order level, such as catfish, sharks, and stingrays. However, the full diversity of species landed is likely to be grossly underestimated given the lack of taxonomic research and knowledge in Timor-Leste.

As a measure of relative abundance or commonness of each species ( $i$ ) in the catch composition, an index of relative importance (IRI) (Kolding, 1989) is used:

$$
\% I R I_{i}=\frac{\left(\% W_{i}+\% N_{i}\right)-\% F_{i}}{\sum_{j=1}^{S}\left(\% W_{j}+\% N_{j}\right)-\% F_{j}}-100
$$

where $\% W_{i}$ and $\% N_{i}$ is percentage weight and number of each species $(i)$ of total catch, $\% F_{i}$ is percentage frequency of occurrence of each species in the total number of samples, summed over all species from $j=1$ to $S$.

Diversity and relative evenness of catch assemblages were compared by habitat and landing site using Shannon's Diversity $(\mathrm{H})$ and evenness $(\mathrm{J})$ indices, calculated in the $\mathrm{R}$ environment (R Core Team, 2018) using the vegan package (Oksanen et al., 2018). The \%IRI was calculated using PasGear fisheries analysis software (ver. 2.11, Kolding and Skaalevik) (Kolding, 1999).

\section{RESULTS}

The gear types in use across sites were similar, with gill nets and hand lines predominating, however, in Biacou and Vemasse the use of specialized scoop seine net gear for FAD fishing was documented. The FADs deployed as part of this study were open access in all sites except Vemasse, where FADs were incorporated into existing FAD fishing groups that manage and fish at specific FADs, invest in gear, and hold shares of the catch. Catch success on FADs in Vemasse was reportedly sporadic, often catching nothing, and highly seasonal, but on good days the daily catch value could exceed USD \$1000 (almost paying for the FAD costs in one day).

A total of $26.7 \mathrm{t}$ of fish and invertebrates were recorded from 184 fishers on 3,277 fishing trips across the four sites between April 2017 and March 2018. Landings were comprised of at least 66 species. Catch rates were variable across space and time, with the highest overall mean catch rate of $2.78 \mathrm{~kg} /($ fisher $\times$ hour) recorded from the community of Adara (Table 2). In terms of fishing effort, FAD fishing was only conducted year-round in Adara, whereas, at other sites, FAD fishing was restricted to certain seasons (Figure 2). In Biacou there were not sufficient data collected to assess fishing behavior year-round.

\section{Effort and Boat Activity Estimation}

The mean distance of deployed FADs from shore was $2 \mathrm{~km}$. The average range $( \pm S D)$ of motorized boats across all sites was $5.4 \mathrm{~km} \pm 2.9$, and non-motorized boats was $1.6 \mathrm{~km} \pm 1.5$. Across all sites, paddle canoes averaged 8.2 trips per month, and the average trip length was $3 \mathrm{~h}$ and $22 \mathrm{~min}$, with a median effort of 4 fisher-hours (including fishing and traveling time). Motorized boats went out for an average of $4 \mathrm{~h}$ and 4 min per trip, with a median effort of 10 fisher-hours per trip and an average of 15.3 trips per month. Reef-fishing was associated with the shortest mean trips, with a mean duration of $2.93(2.38 / 3.71) \mathrm{h}$ per trip (Poisson mean with asymmetric $95 \%$ confidence bounds in parentheses). FAD fishing was similar in duration to other habitat types, accounting for $3.5(2.83 / 4.42) \mathrm{h}$ per trip and mangrove and deep sea for 3.4 $(2.76 / 4.27) \mathrm{h}$ per trip on average. Site-specific VACs are shown in Table 2.

\section{Effects of FADs on Production}

After accounting for random site variation, we observed a significant positive effect of FADs on productivity, with a mean CPUE value of $2.17(1.84 / 2.54) \mathrm{kg} /($ fisher $\times$ hour $)$ for FAD-associated fishing (Poisson mean with asymmetric 95\% confidence bounds shown in parentheses), compared with $1.21(0.97 / 1.51) \mathrm{kg} /($ fisher $\times$ hour) for reef fishing and $0.8(0.68 / 0.93) \mathrm{kg} /($ fisher $\times$ hour $)$ for other habitats (beach, mangrove, and deep sea; Table 3). Disaggregation by site revealed that this pattern was primarily driven by Adara and Vemasse, whose FAD-associated CPUE values were 2.8 and $5.3 \mathrm{~kg} /($ fisher $\times$ hour), respectively (Figure 3 and Table 3). A similar pattern was observed when considering CPUE in terms of the number of fish caught per fisher-hour. FAD-associated catches averaged 13.7 (9.8/19.1) fish/hour, which was higher than that observed for reef-fishing [2.49 $(1.75 / 3.53)]$, or beach, deep sea and mangrove-fishing [9.2 $(6.59 / 12.85)]$. This was also primarily driven by Adara and Vemasse, with average CPUE values of 8 and 40.2 fish/hour, respectively.

The trip success rate was relatively constant across habitats and sites, with around $90 \%$ of trips producing a non-zero catch on aggregate for most of the sites. The exception was Biacou, where the trip success rate ranged from $54-76 \%$ depending on the habitat type. Here, reef fishing was generally the most likely method to experience a non-zero catch (76\%), while FAD, deep, beach, and mangrove showed a similarly low trip success rates of $54-62 \%$.

TABLE 2 | General catch statistics by landing site of four small-scale fishing communities in Timor-Leste.

\begin{tabular}{|c|c|c|c|c|c|c|c|c|c|c|c|}
\hline Site & $\begin{array}{c}\text { Diversity } \\
\text { (Shannon's H) }\end{array}$ & $\begin{array}{c}\text { Evenness } \\
\text { (Shannon's J) }\end{array}$ & $\begin{array}{c}\text { VAC } \\
\text { [hr/(month } \times \\
\text { boat)] }\end{array}$ & $\begin{array}{l}\text { Recorded catch } \\
\times \quad \text { (N fishes) }\end{array}$ & $\begin{array}{l}\text { Recorded } \\
\text { catch }(\mathbf{k g})\end{array}$ & $\begin{array}{l}\text { Recorded } \\
\text { effort (h) }\end{array}$ & $\begin{array}{l}\text { Mean trip } \\
\text { time (h) }\end{array}$ & $\begin{array}{c}\text { CPUE } \\
\text { [kg/(fisher } \times \\
\text { hour)] }\end{array}$ & $\begin{array}{c}\text { Motorized } \\
\text { vessels }\end{array}$ & Canoes & $\begin{array}{c}\text { Total } \\
\text { catch }(t)\end{array}$ \\
\hline Adara & 1.28 & 0.37 & 19.13 & 19288 & 6675 & 2729 & 2.5 & 2.78 & 3 & 12 & 28.4 \\
\hline Adarai & 0.4 & 0.13 & 53.42 & 32875 & 3360 & 3210 & 3.21 & 0.97 & 12 & 60 & 44.3 \\
\hline Biacou & 1 & 0.26 & 46.74 & 73302 & 5888 & 7367 & 4.32 & 0.92 & 41 & 8 & 72.5 \\
\hline Vemasse & 1.16 & 0.43 & 76.24 & 106626 & 10761 & 5669 & 3.97 & 0.94 & 9 & 23 & 24.1 \\
\hline
\end{tabular}




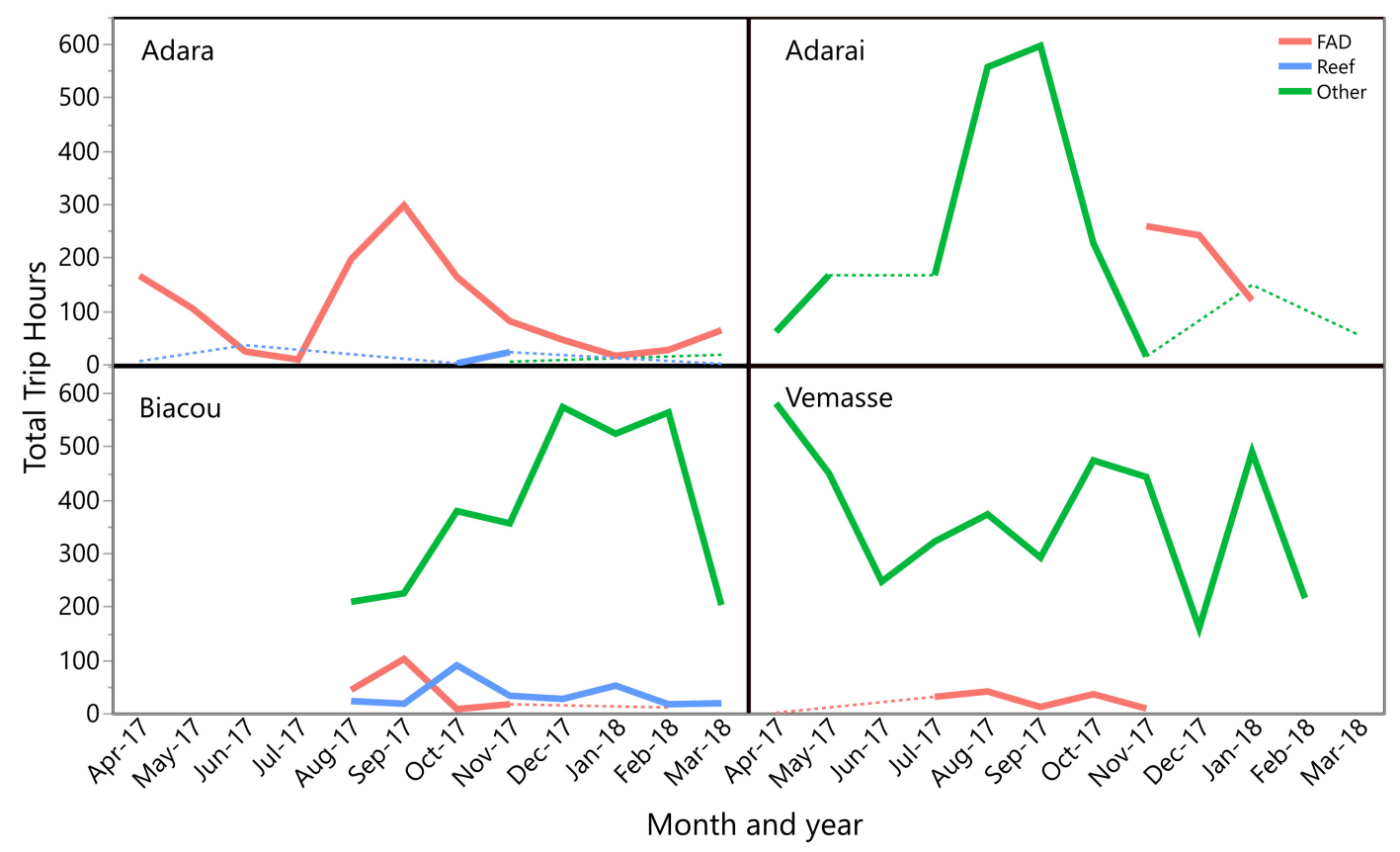

FIGURE 2 | The total number of fishing trips for which catch was recorded, by month and habitat at four sites in Timor-Leste. Solid lines represent continuous data. Connecting dotted lines reflect no data.

\section{Total Production and Cost-Benefit Analysis of FADs}

The highest estimated total annual production was seen in Biacou with $72.5 \mathrm{t}$, followed by Adarai with $44.3 \mathrm{t}$ of fish landed during the 12-month study period (Table 2). The mean longevity of FADs deployed in this study was 11 months. The mean price per kilogram of fish landed was USD $\$ 2.49 / \mathrm{kg}$, with slight variations by site (Table 4). Using an approximate FAD investment cost of $\$ 1250$ to account for equipment, construction and deployment, and assuming consistent steady catch rates throughout the year, the time to $100 \%$ return on investment ranged from 18 days in Vemasse to 3343 days in Biacou (Table 4). However, based upon large variations between sites in terms of total effort, catch volumes, FAD fishing frequency and proportion of catch sold, the RoI varied significantly according to the site (Table 4). In Biacou, FAD fishing did not show significantly higher catch rates, so a RoI will likely never be realized in the lifetime of the FAD.

\section{Catch Assemblage Species Diversity}

Fish aggregating device catches across all locations was dominated by three species, the short-bodied scad (Rastrelliger brachysoma), the mackerel scad (Decapterus macarellus), and sardines (likely to represent a complex of up to five locally occurring species due to difficulties in identification), which comprised 96\% (IRI) of landings. Adarai and Biacou are for the most part single species fisheries, with $>90 \%$ of their catches comprised of $R$. brachysoma (99.6\%) and sardines (Sardinella spp.) (92.1\%), respectively. In Vemasse $92.2 \%$ of the catch was of two species (D. macarellus, $79.8 \%$ and Sardinella spp. 12.4\%). Sardines are only found in catches from mainland sites. In
Adara on Atauro Island, the top three species (R. brachysoma, D. macarellus, and Pterocaesio tile - striped fusilier) account for $98 \%$ of the catch (Figure 4).

Catch assemblages from reef fishing were much richer in species than from FAD fishing, with Shannon's diversity scores of 2.4 for reef compared to 0.98 for FADs (Table 3 and Figure 4). The highest biodiversity in catch assemblages was seen from reef fishing in Biacou (2.48). Many of the species included in FAD catch assemblages can be accounted for by fishers' catches in reef habitat on the way back to shore from the FAD. Landings records were not of sufficient granularity to account for multiple habitats fished per trip.

\section{DISCUSSION}

This study shows that nearshore FADs can be a cost effective tool to increase catch rates of non-reef fish in rural coastal fisheries, without necessitating a transfer to new gears or methods. However, where more specialized fishing and gears were deployed, the results were even more pronounced. These results suggest that the incorporation of nearshore FAD deployments with fishery closures of nearshore reef areas, as employed in emergent marine resource co-management in Timor-Leste (Tilley et al., 2019), could be a potential way to mitigate common livelihood costs to fishers caused by displaced fishing effort (Cinner et al., 2014). However, to maximize the rate of return on investment, the selection of sites for FAD deployments should be carefully explored to account for social and ecological aspects. In the following sections, we explore the effect of FADs on fisheries production, biodiversity, and food security while evaluating the 


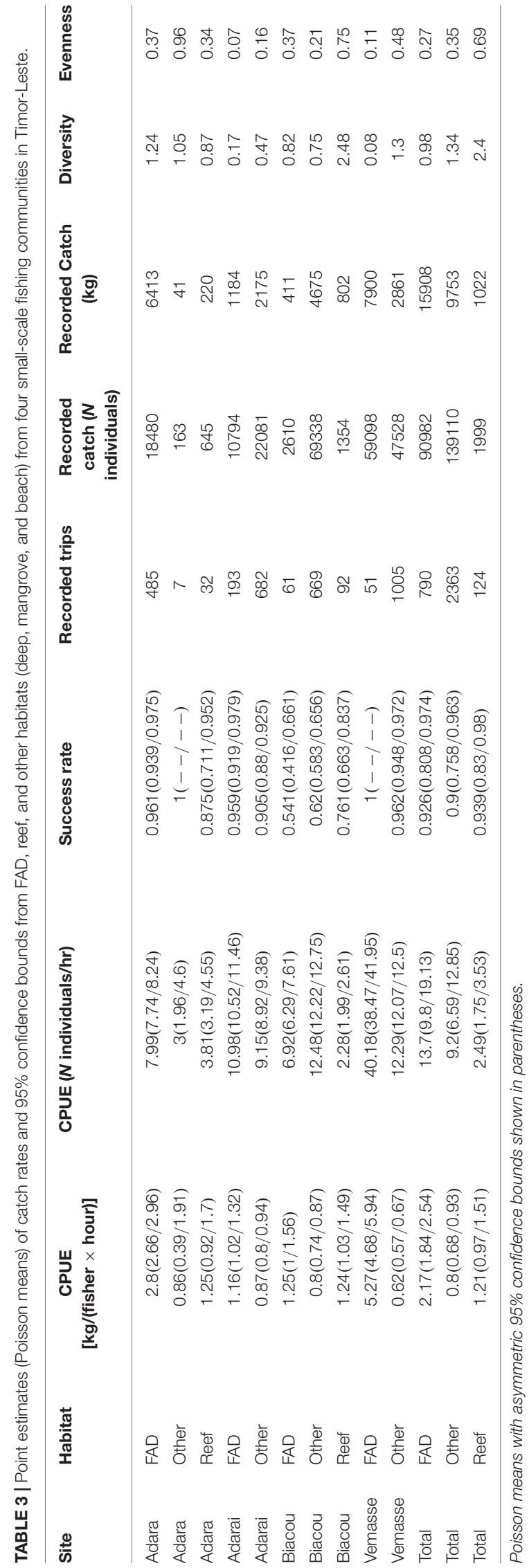

opportunities and constraints of scaling FAD deployment in Timor-Leste with the aim of providing recommendations for a government-led, national level FAD programme.

\section{Effects of FADs on Catch Rates and Effort}

Results suggest that despite high site variability, fishing on FADs resulted in higher catch rates per unit of effort $[\mathrm{kg} /($ fisher $\times$ hour $)]$ than other habitat types. Greater amounts of fish being landed that can be distributed, is the first step toward improving rural access to fish and the critical micronutrients they provide. Timor-Leste waters are thought to be relatively unproductive, but average reef catch rates found here are similar to those reported in Fiji [0.9-1.6 kg/(fisher $\times$ hour)] (Kuster et al., $2005)$ and Apo Island in the Philippines [1-2 kg/(fisher $\times$ hour)] (Maypa et al., 2002). Additionally, nearshore FAD and non-FAD catch rates are comparable to neighboring countries in AsiaPacific such as the Solomon Islands, where FAD fishing rates were reported from 1.04 to $2.96 \mathrm{~kg} /($ fisher $\times$ hour) and nonFAD fishing from 0.87 to $2.16 \mathrm{~kg} /$ (fisher $\times$ hour) (Albert et al., 2014). Most studies on the effects of FADs on increasing catch rates are assessing FADs placed many miles offshore, targeting tuna, and thus are not applicable for an artisanal fleet consisting of mostly paddle canoes fishing on fringing reefs. There is far less information available on the effects of nearshore or coastal FADs [defined as within 12 nautical miles of shore (Gillett, 2016), but typically not more than 3 miles from the coast]. In Niue, nearshore FADs increased catch rates by only $27 \%$ over a 2 year period, compared to an offshore catch rate increase of $113 \%$ (Sharp, 2011). Other reported offshore annual gains reach even higher magnitudes, such as $340 \%$ in La Reunion (Detolle et al., 1998 ) and $1120 \%$ in Mauritius (Beverly et al., 2012).

Our findings support the positive FAD effects seen in other studies, but also confirm the significant variability between sites as seen in the Solomon Islands (Albert et al., 2014). Unfortunately due to relatively small number of data points and potential confounding of various factors affecting catch and effort (fishers utilizing habitat specific gear types, e.g., seine nets on FADs) we were unable to completely tease apart the effects of aggregation devices from variation among additional measured and non-measured factors, such as fishing gear type, substrate type, bathymetrical features, proximity to markets and human population centers, etc. Numerous factors affect catch rates, and there is no accepted justification for standardizing CPUE by the amount of fishing time when combining an active method, such as spearfishing, with a passive method, such as gill nets (GibsonReinemer et al., 2017). In using raw CPUE standardized by time, our study incorporates a significant statistical assumption in considering that the various gear types have equal catchability coefficients [the portion of the stock captured by one unit of effort (Maunder et al., 2006)], or even the same gear type is equal among fishers (e.g., using the same length gill net). However, the diversity and complexity of small-scale, mixed species fisheries make the adequate standardization of effort (see Maunder and Punt, 2004) for this type of study impractical. Furthermore, in a livelihood context, relevant considerations of "effort" are 


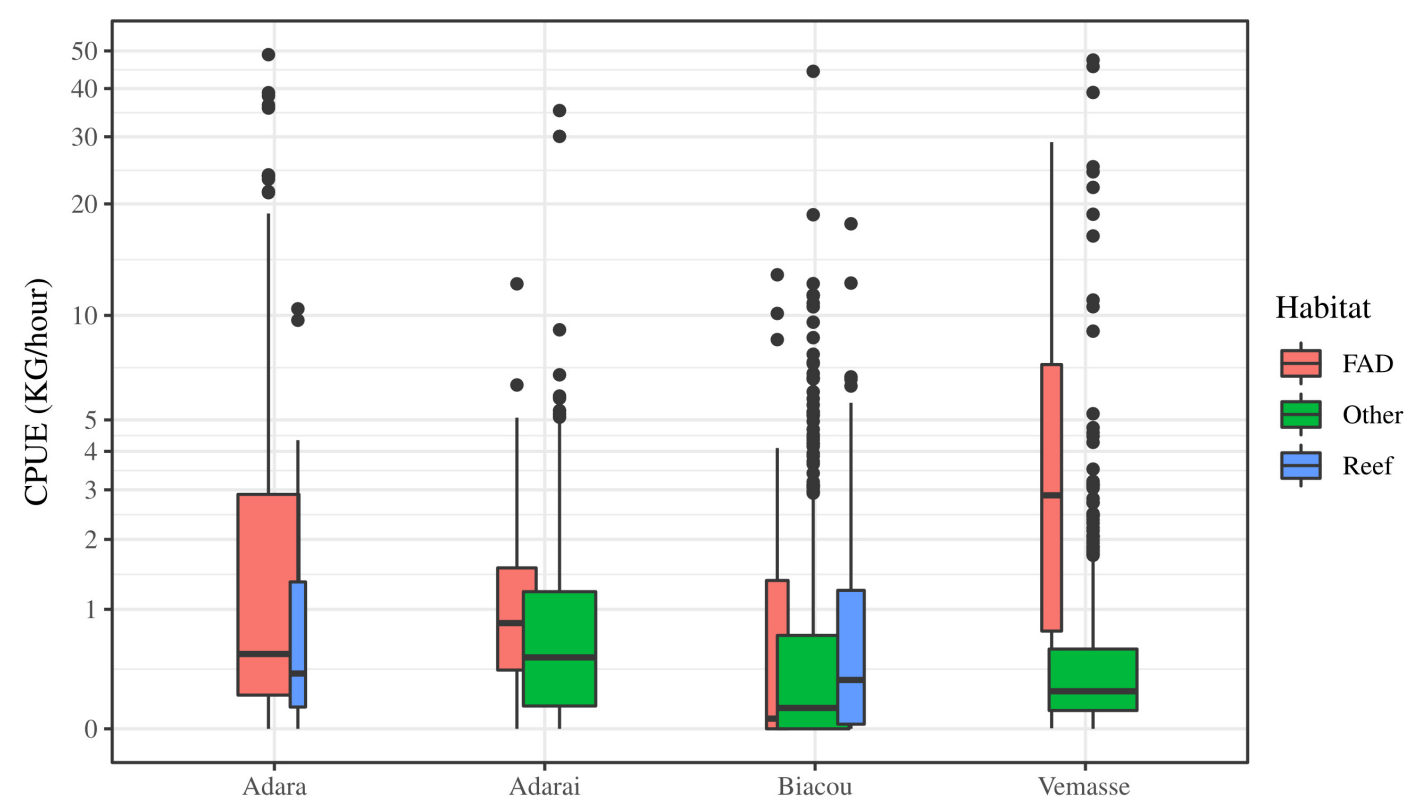

FIGURE 3 | Comparison of catch rates of FAD fishing, reef fishing, and other fishing across four sites in Timor-Leste using the weight of fish per fisher hour on a log axis (data untransformed). Trip records other than to FADs and reefs in Adara are not shown due to the low number of observations ( $n=7$ ). Box width is proportional to the number of observations for each site/habitat combination. Box midlines reflect the median values, box boundaries show lower and upper hinges (first and third quartiles - or 25th and 75th percentiles), and whisker limits are $1.5 \times$ interquartile range. Outliers beyond these limits are shown as points.

energetic expenditure and time. We did not have the capability to measure energetic expenditure of fishers, so the key insight into comparable effort is the time expended (that could otherwise have been committed to alternative livelihood activities). Under these assumptions, our results indicate a positive net effect of FADs on overall catch rates, with corresponding positive effects on rates of return on FAD investment at local and regional scales.

The highest catch rates for FADs compared to other habitats in Timor-Leste were seen from the site of Vemasse. This community has been deploying traditional FADs of their own for the past few years and have created FAD fishing groups of $\sim 12$ people who hold varying numbers of catch shares based on their investment in the equipment or labor. These FAD groups also utilize a specialized fishing technique documented in Mills et al. (2013) where lights are deployed above the FAD before dawn, then a modified scoop-seine net is deployed around the schooling fish. Even incorporating the additional investment costs of specialized seine net fishing gear ( USD \$1,000, Vemasse fisher pers. comm.), the time to $100 \%$ RoI would be $\sim 33$ days. At the other three sites, fishers predominantly using gill nets and hand lines on
FADs, just as in reef and open water areas, with some infrequent use of scoop seine nets in Biacou, but without the organized FAD group structure.

In Biacou, fishers traditionally focus on pelagic species. Analysis of vessel movements from GPS tracking show this pattern clearly, with the mean trip range $( \pm$ SD) of vessels in Biacou reaching $7.5 \mathrm{~km} \pm 3.4$ ), which is more than double that of all other sites (Adara: $1.4 \mathrm{~km} \pm 2.6$; Adarai: $2.2 \mathrm{~km} \pm 1.3$; and Vemasse: $3.5 \mathrm{~km} \pm 3.5$ ) (Figure 5). This existent capacity to fish further offshore may account for no apparent differences between FAD fishing catch rates and other fishing, but the lack of year round data from Biacou make this inconclusive. The highly variable success of FADs seen in our results, suggests that the location of nearshore FAD deployments in Timor-Leste needs to be selected carefully based on gear types already in use and catch rates, and should incorporate the collection of some baseline catch monitoring from potential sites. These findings corroborate those of Albert et al. (2014) in the Solomon Islands, where villages presenting low catch rates, limited diversity of fishes, or degraded reef fisheries, were likely to benefit the most from access to a

TABLE 4 | Site-based Returns on Investment (Rol) in days for nearshore FADs at four sites in Timor-Leste.

\begin{tabular}{|c|c|c|c|c|c|c|c|}
\hline Site & FAD trips/total trips $(F)$ & Total Boats $(N)$ & $V A C_{\text {day }}(\mathrm{h})$ & $\triangle C P U E$ & Price of fish $(\$ / \mathbf{k g})$ & Proportion of catch sold (S) & Rol (in days) \\
\hline Adara & 0.82 & 15 & 0.64 & 1.55 & $\$ 1.81$ & 0.37 & 154 \\
\hline Adarai & 0.27 & 72 & 1.78 & 0.29 & $\$ 2.19$ & 0.69 & 82 \\
\hline Biacou & 0.21 & 49 & 1.56 & 0.01 & $\$ 2.80$ & 0.83 & 3355 \\
\hline Vemasse & 0.52 & $9 *$ & 2.54 & 4.65 & $\$ 2.12$ & 0.59 & 18 \\
\hline
\end{tabular}

Variables for the calculation of Rol are in bold, following Eq. 3. *In Vemasse only motorboats fished on FADs so canoes were excluded from the calculation of Rol. 


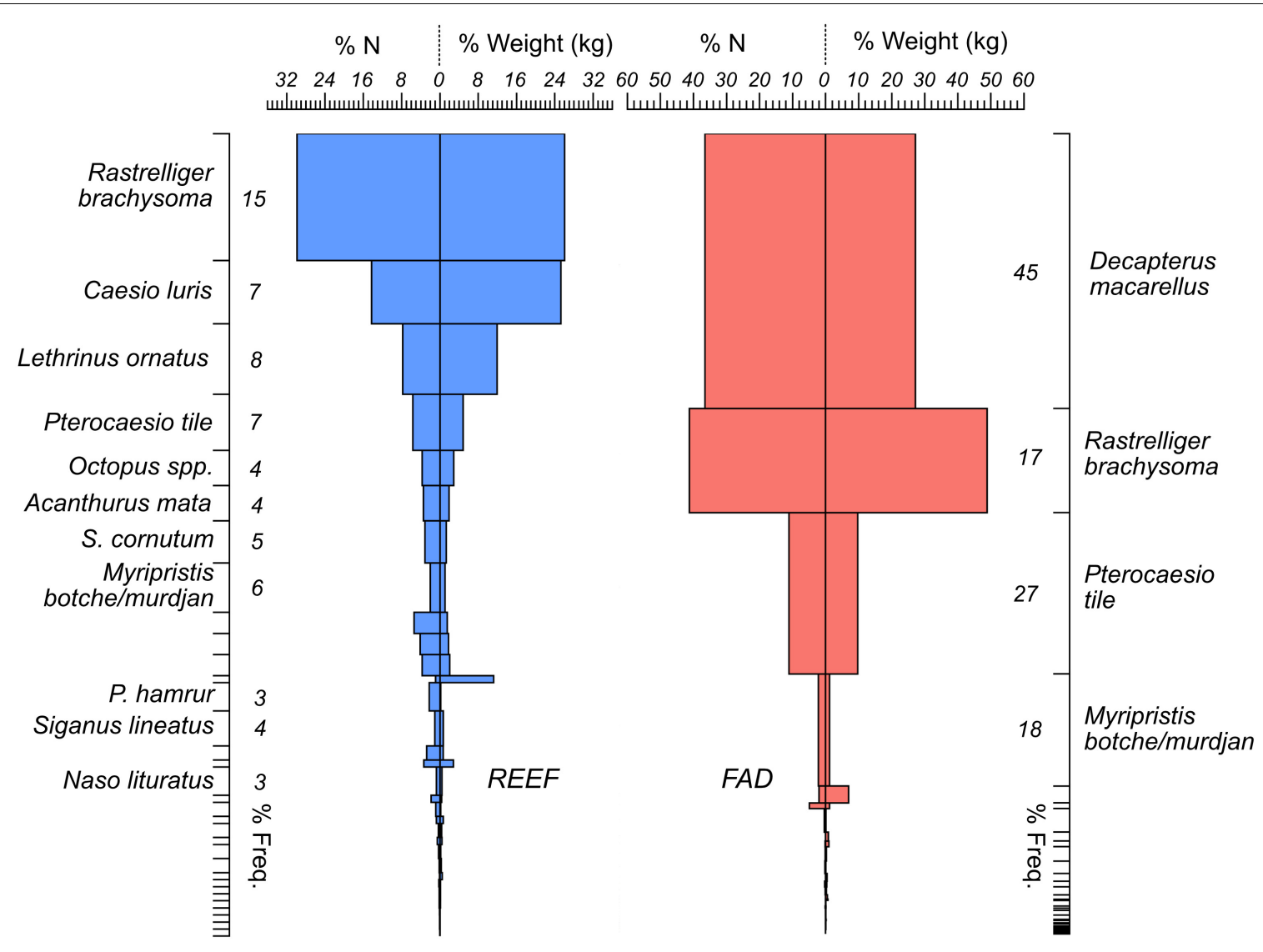

FIGURE 4 | Catch composition for small-scale fisheries landings from reef and FAD fishing from Adara, Atauro Island, Timor-Leste. The size of the box represents the $\%|R|$ of each species in each location, where $\% N$ is the proportion of total individuals, \%Freq is the proportion of total samples, and \%Weight is the proportion of total weight landed.

nearshore FAD. However, appropriate management steps should also be taken to ensure that this trend degradation does not merely transfer to pelagic fisheries, as improved catch rates can imply faster depletion of resources (Cabral et al., 2014).

\section{Catch Assemblages and Biodiversity}

Previous evaluations of sustained FAD programs suggest that in sites where pelagic resources are underutilized, they can bring considerable increases in fish yields through access to alternative resources (Beverly et al., 2012). The nearshore FADs studied here aggregate small, highly mobile pelagic fishes such as mackerels and scads, which are highly productive and can sustain relatively high levels of fishing pressure (Dalzell and Lewis, 1989; Dalzell, 1993). By providing access to an additional or more abundant source of fish, artisanal fishing effort may be reallocated from often heavily exploited coastal reef habitats (Beverly et al., 2012; Bell et al., 2015a). For example, catch rate increases in Mauritius were seen to coincide with a substantial and associated decrease in fishing effort in nearby lagoons, analogous to a reduction in pressure on reef systems (Beverly et al., 2012). Catch sampling was not sufficiently uniform to highlight changes in fishing effort on reefs, as the same fishers were not recorded every day. Fishing effort data before and after FAD deployments showed no significant increase or decrease on reef habitats specifically. However, redistribution of fishing effort in proportion to catch rates is a common phenomenon in SSF (Gillis et al., 1993; Gillis, 2003; López-Angarita et al., 2018; Peter and van Zwieten, 2018), suggesting that as fishers notice increasing catch rates at FADs, we are likely to see a geographical shift in effort.

A fisher focus group in Adara commented that the primary value of FADs for them was not larger catches, because there was a limit to what they could sell, but rather the reduced time taken to catch a sufficient quantity of fish, thereby allowing additional time to be dedicated to other livelihoods such as cultivating land and tending livestock. In a recent study from Timor-Leste, Mills et al. (2017) show that those households that fished year round had significantly better food security, and a lower number of livelihoods than seasonal fishers or farming households. FADs may have a very important role to play in this space, especially in areas of acute seasonal food shortages, to reduce vulnerability to shocks. Data collection on SSF and FADs in Timor-Leste is still ongoing. In future, we hope that a longer time series allows the testing of seasonality on fishing effort and catch rates.

Deploying nearshore FADs outside of designated no-take marine areas is a strategy that has been shown to contribute to marine protected area success in terms of recovery of 


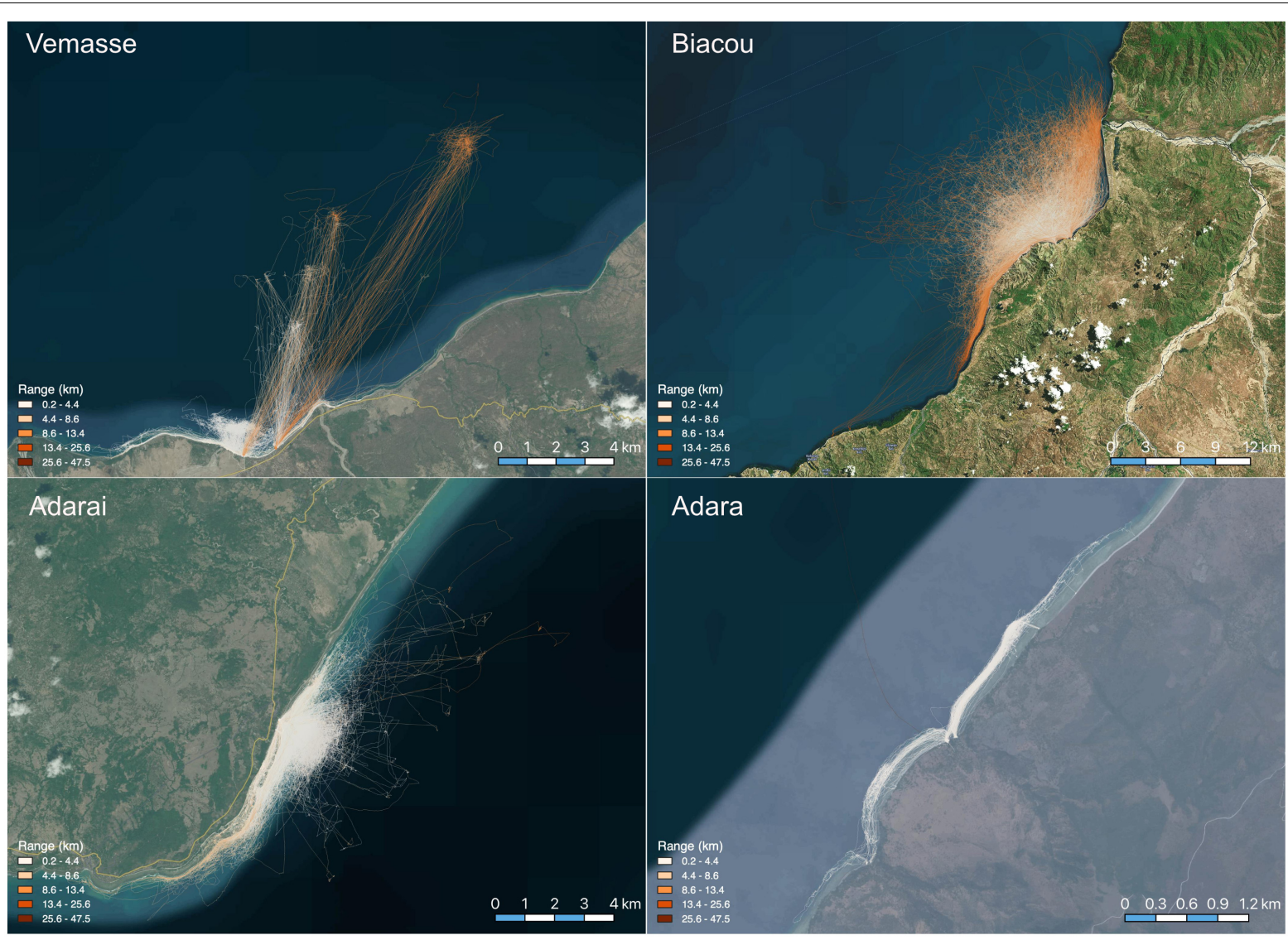

FIGURE 5 | Comparison of fishing behavior and trip range using tracks gathered by solar-powered vessel tracking systems by Pelagic Data Systems in four community sites around Timor-Leste between February and October 2018. The color gradient reflects the trip range, with the longest trips shaded in red and the shortest in white. The number of tracks represented in each pane are Vemasse 437, Biacou 1387, Adara 175, and Adarai 1256 (OPelagic Data Systems. Satellite imagery@2018 HERE).

tropical marine habitat and recovery of fish stocks, as well as compensating for loss of fishing grounds for income of food for fishers (Gell and Roberts, 2003). In Adara, the community's revival of traditional practices of resource management called tara bandu, included the establishment of a closed area to fishing, where divers and snorkelers are charged a small entry fee (Mills and Tilley, 2017). According to community members, the accrual of this money for community development projects, and the regularity of fishing yields provided by the FADs have had a substantial effect on community livelihoods and wellbeing (Mills and Tilley, 2017). The emergence of co-management mechanisms of governance in Timor-Leste could leverage the potential of FADs even further to achieve combined conservation and sustainable development outcomes (Tilley et al., 2019).

\section{Opportunities and Constraints to Scaling FAD Deployment}

All the FADs assessed in this study were theoretically open access, to at least community level, and were all within $4 \mathrm{~km}$ of the shore to allow for all fishers to access - not just those with motorboats. However, a focus group discussion with fishers in
Vemasse revealed the development of informal user-rights, where each FAD is "owned" by a group that has the exclusive rights to fish on it. This may account for the significantly higher catch rates and faster RoI in Vemasse (18 days) and highlights the potential importance of clearly defined boundaries in managing common resources (Ostrom, 1990), even if these are not necessarily legally recognized boundaries (Govan, 2009). Furthermore, this adheres to current ideas around best practice specific to FAD management (Beverly et al., 2012), where sustainable exploitation of resources is achieved through local stewardship and a sense of ownership.

By diversifying and enhancing the supply of fish, it is thought that fisher households will be more resilient to natural disasters, social and political instability, and climate variability (Bell et al., 2015a). This is because pelagic and reef species will likely respond very differently to broadscale environmental changes or local pressures such as coastal development or reef degradation. Other suggested social benefits of FAD programs include increased employment opportunities, development of supporting industries, and improved nutrition (Sims, 1988). However, as FADs enable access to fishing areas further from the coast than traditional fishing areas, safety at sea becomes an important risk factor for fishers, as they 
face different environmental conditions. Research regarding safety at sea in Timor-Leste is limited, but it has been reported that the major cause of accidents at sea is saltwater crocodile attacks followed by boat accidents due to sudden bad weather (Alonso et al., 2012). A survey conducted in 2012 showed that despite $97 \%$ of fishers identifying bad weather and big waves as a predominant problems faced at sea, $64 \%$ did not have safety equipment on board, mainly because it was overly expensive and considered unnecessary (Tsujimura et al., 2012). Given that there is currently no specific regulation on safety at sea for small-scale fishers in TimorLeste, developing a legal framework alongside a FAD program will be important.

Nearshore FADs are not new to Timor-Leste. They are thought to have been introduced during the Indonesian occupation, and as such are already deployed independently by some communities on mainland Timor. On Atauro Island, FADs are notoriously difficult to deploy and maintain (Mills et al., 2013), due to strong currents and steep slopes to depths exceeding $4000 \mathrm{~m}$. The average duration of FADs in the water across all locations was 11 months, which is significantly shorter than the lifespan of FADs in the Pacific, with the minimum expectation being 2 years, with some extending to 8 years (Sharp, 2011). However, this again is seemingly site and depth (Table 1) dependent, as the two FADs deployed on Timor-Leste's south coast have been in place for 20 months as of December 2018.

In experimenting with FAD designs, the materials from which FADs were constructed by WorldFish and MAF were more expensive than might be utilized in a larger scale deployment program. Assuming equal efficacy at aggregating fish of low and high-cost FADs, this indicates RoI would be achieved even faster by reducing the initial investment cost. Beverly et al. (2012) suggest that quality should not be compromised because of funding and that a few wellmade FADs are better than many of low quality that may be quickly lost. This, of course, makes economic sense in exploiting returns, and environmental sense in reducing the contribution of marine debris with broken and dislodged FADs (Macfadyen et al., 2009). However, there are instances when low-cost deployments may be preferable. If FADs are employed as a strategy by individual fishing groups in coastal communities (as opposed to a government program), they may lack the resources to purchase higher quality ropes and buoys. Furthermore, in Vemasse and Adarai, fishing on the FADs was only conducted seasonally when conditions were favorable, indicating a year-round FAD may be subject to wear and tear and be accumulating biofouling for a significant amount of time while it is not being fished. In this instance, low-cost FADs would be more appropriate.

Fish aggregating devices were not maintained in any organized or regular manner by fishers during this period. Maintenance programs, such as regular removal of barnacles and other biofouling organisms growing on the rope can reduce overloading of the buoys and increase FAD longevity (Beverly et al., 2012). At sites of increased FAD CPUE the average RoI was just 85 days, but intuitively, FAD longevity has a direct and significant effect on overall revenue generated. As with any financial investment, trade-offs of risks and gains scale with the number of shares, and in certain parts of TimorLeste, the risks of losing FADs are significant. Hence, by encouraging and training fishers to act cooperatively in FAD fishing and management, individual risks to already vulnerable fishers with limited capital can be minimized, and benefits can be maximized.

\section{CONCLUSION}

- Near-shore deployed FADs for pelagic species can significantly improve artisanal catch rates and overall production at suitable localities in Timor-Leste; with specialized gear investment showing optimal return rates.

- Where a return on investment is seen, it is rapid and is indicative that government investment in FAD programmes would provide a substantial benefit to fishers and communities. FADs should not exceed $2 \mathrm{~km}$ from the coast to ensure paddle canoe fishers can access and thereby distribute benefits to the poorest fishers who are most likely to gain from even small improvements to catch rates.

- Given the heightened risk of accidents at sea related to fishing in FAD areas, the development of legal provisions that facilitate implementing measures for safety at sea is important. These should include increasing the capacity of the authorities, boat builders and fishers in safety measures, from boat building and maintenance to rescue operations.

- Fishers should be encouraged to form cooperative or group arrangements to reduce risk and improve livelihood resilience through better access to credit, product and insurance markets, and educational and training services.

- Catch rates improved by FADs could lead to faster depletion of resources in fish stocks of unknown biomass and productivity so communities supported by a FAD program should be encouraged and empowered to management through the collection of catch and effort data.

\section{AUTHOR CONTRIBUTIONS}

AT and DM designed the study. AT, MP, and SW collected the data. AT, SW, and JK analyzed the data. AT, SW, JK, DM, and JL-A wrote the manuscript.

\section{FUNDING}

This work was undertaken as part of the CGIAR Research Program on Fish Agri-Food Systems (FISH) led by WorldFish. This study was carried out under the Fisheries Sector Support Program funded by the Royal Norwegian Embassy in Jakarta, an Inspire Challenge 2018 Award from the CGIAR Platform for Big Data in Agriculture (AT), and an Australian Centre for International Agricultural Research grant (FIS/2010/097) exploring options for improving livelihoods and resource management in Timor-Leste's coastal communities. 


\section{ACKNOWLEDGMENTS}

We would like to thank the fishers and their communities for trusting us and working with us to test fish aggregating devices (FADs) in their resource areas.

\section{REFERENCES}

Albert, J. A., Beare, D., Schwarz, A.-M., Albert, S., Warren, R., Teri, J., et al. (2014). The contribution of nearshore fish aggregating devices (FADs) to food security and livelihoods in Solomon Islands. PLoS One 9:e115386. doi: 10.1371/journal. pone. 0115386

Alonso, E., Wilson, C., Rodrigues, P., Pereira, M., and Griffiths, D. (2012). Policy and Practice: Recommendations for Sustainable Fisheries Development in TimorLeste. Bangkok: Regional Fisheries Livelihoods Programme for South and Southeast Asia.

Alonso Población, E. (2013). Fisheries and food security in Timor-Leste the effects of ritual meat exchanges and market chains on fishing. Food Secur. 5, 807-816. doi: 10.1007/s12571-013-0308-2

AMSAT International, (2011). Fish and Animal Protein Consumption and Availability in Timor-Leste. Regional Fisheries Livelihoods Programme for South and Southeast Asia (GCP/RAS/237/SPA). Field Project Document 2011/TIM/02. Silver Spring, MD: AMSAT.

Bates, D., Mächler, M., Bolker, B., and Walker, S. (2015). Fitting linear MixedEffects models using lme4. J. Stat. Softw. 67, 1-48.

Bell, J. D., Albert, J., Amos, G., Arthur, C., Blanc, M., Bromhead, D., et al. (2018). Operationalising access to oceanic fisheries resources by small-scale fishers to improve food security in the Pacific Islands. Mar. Policy 88, 315-322. doi: 10.1016/j.marpol.2017.11.008

Bell, J. D., Albert, J., Andréfouët, S., Andrew, N. L., Blanc, M., Bright, P., et al. (2015a). Optimising the use of nearshore fish aggregating devices for food security in the Pacific Islands. Mar. Policy 56, 98-105. doi: 10.1016/j.marpol. 2015.02.010

Bell, J. D., Allain, V., Allison, E. H., Andréfouët, S., Andrew, N. L., Batty, M. J., et al. (2015b). Diversifying the use of tuna to improve food security and public health in Pacific Island countries and territories. Mar. Policy 51, 584-591. doi: 10.1016/j.marpol.2014.10.005

Bell, J. D., Kronen, M., Vunisea, A., Nash, W. J., Keeble, G., Demmke, A., et al. (2009). Planning the use of fish for food security in the Pacific. Mar. Policy 33, 64-76. doi: 10.1016/j.marpol.2008.04.002

Bellwood, D. R., Hughes, T. P., Folke, C., and Nyström, M. (2004). Confronting the coral reef crisis. Nature 429, 827-833. doi: 10.1038/nature02691

Beverly, S., Griffiths, D., and Lee, R. (2012). Anchored fish Aggregating Devices for Artisanal Fisheries in South and Southeast Asia: Benefits and Risks. Bangkok: FAO Regional Office for Asia and the Pacifi.

Cabral, R. B., Porfirio, M. A., and Lim, M. T. (2014). Modelling the impacts of fish aggregating devices (FADs) and fish enhancing devices (FEDs) and their implications for managing a small-scale fishery. ICES J. Mar. Sci. 71, 1750-1759. doi: $10.1093 /$ icesjms/fst229

Campbell, B., Hanich, Q., and Delisle, A. (2016). Not just a passing FAD: insights from the use of artisanal fish aggregating devices for food security in Kiribati. Ocean Coast. Manag. 119, 38-44. doi: 10.1016/j.ocecoaman.2015.09.007

Cinner, J. E., Daw, T., Huchery, C., Thoya, P., Wamukota, A., Cedras, M., et al. (2014). Winners and losers in marine conservation: fishers' displacement and livelihood benefits from marine reserves. Soc. Nat. Resour. 27, 994-1005. doi: 10.1080/08941920.2014.918229

Connell, J. (2013). Islands at Risk: Environments, Economies and Contemporary Change. Cheltenham: Edward Elgar Publishing.

Dalzell, P., and Lewis, A. D. (1989). A review of the south pacific tuna bait fisheries: small pelagic fisheries associated with coral-reefs. Mar. Fish. Rev. 51, 1-10.

Dalzell, P. J. (1993). "Small pelagic fishes," in Nearshore Marine Resources of the South Pacific, eds A. Wright and L. Hill (Suva: Forum Fisheries Agency, Honiara and Institute of Pacific Studies), 97-133.

Dempster, T., and Taquet, M. (2004). Fish aggregation device (FAD) research: gaps in current knowledge and future directions for ecological studies. Rev. Fish Biol. Fish. 14, 21-42. doi: 10.1007/s11160-004-3151-x
We were also indebted to officers of the National Fisheries Directorate of the Government of TimorLeste's Ministry of Agriculture and Fisheries for their ongoing partnership and assistance in building and deploying FADs.

Désurmont, A., and Chapman, L. (2000). "The use of anchored FADs in the area served by the Secretariat of the Pacific Community (SPC): regional synthesis," in Pêche thonière et dispositifs de concentration de poissons, Caribbean-Martinique.

Detolle, J. P., Tessier, E., Roos, D., René, F., and Sacchi, J. (1998). The dynamics and effects of FADs in La Reunion Island. SPC Fish. Newsl. 3, 19-23.

FAO, (2009). Global Agriculture Towards 2050 - High Level Expert Forum - How to Feed the World in 2050. Rome: FAO.

FAO, (2018). The State of World Fisheries and Aquaculture: Meeting the Sustainable Development Goals. Rome: The Food and Agriculture Organisation of the UN.

Feeny, S., and McGillivray, M. (2010). Aid and growth in small island developing states. J. Dev. Stud. 46, 897-917. doi: 10.1080/002203810036 23889

Fox, J. (2003). Effect displays in R for generalised linear models. J. Stat. Softw. $8,1-27$.

Gell, F. R., and Roberts, C. M. (2003). The Fishery Effects of Marine Reserves and Fishery Closures. Washington, DC: WWF.

Gibson-Reinemer, D. K., Ickes, B. S., and Chick, J. H. (2017). Development and assessment of a new method for combining catch per unit effort data from different fish sampling gears: multigear mean standardization (MGMS). Can. J. Fish. Aquat. Sci. 74, 8-14. doi: 10.1139/cjfas2016-0003

Gillett, R. E. (2016). Fisheries in the Economies of Pacific Island Countries and Territories. Available at: http://famel.spc.int/en/component/content/article/ 237-benefish-study-2016 (Accessed October 30, 2018).

Gillis, D. M. (2003). Ideal free distributions in fleet dynamics: a behavioral perspective on vessel movement in fisheries analysis. Can. J. Zool. 81, 177-187. doi: $10.1139 /$ z02-240

Gillis, D. M., Peterman, R. M., and Tyler, A. V. (1993). Movement dynamics in a fishery: application of the ideal free distribution to spatial allocation of effort. Can. J. Fish. Aquat. Sci. 50, 323-333. doi: 10.1139/f93-038

GOTL, (2011). Timor-Leste Strategic Development Plan 2011-2030. Dili: TimorLeste Government.

Govan, H. (2009). Status and Potential of Locally-Managed Marine Areas in the Pacific Island Region: Meeting Nature Conservation and Sustainable Livelihood Targets Through Wide-Spread Implementation of LMMAs. Apia: SPREP.

Guyader, O., Bellanger, M., Reynal, L., Demanèche, S., and Berthou, P. (2013). Fishing strategies, economic performance and management of moored fishing aggregating devices in Guadeloupe. Aquat. Living Resour. 26, 97-105. doi: $10.1051 /$ alr/20013044

Hartmann, W. D. (2010). Consultancy to Verify National RFLP Work Plan Activities, Collaborators and Indicators - Final Report on Timor-Leste. Bangkok: Regional Fisheries Livelihoods Programme for South and Southeast Asia.

Hughes, T. P., Baird, A. H., Bellwood, D. R., Card, M., Connolly, S. R., Folke, C., et al. (2003). Climate change, human impacts, and the resilience of coral reefs. Science 301, 929-933. doi: 10.1126/science.1085046

Hughes, T. P., Barnes, M. L., Bellwood, D. R., Cinner, J. E., Cumming, G. S., Jackson, J. B. C., et al. (2017). Coral reefs in the Anthropocene. Nature 546, 82-90.

Kolding, J. (1989). The Fish Resources of Lake Turkana and Their Environment. Cand. Scient, thesis, University of Bergen, Bergen.

Kolding, J. (1999). PasGear: A Database Package for Experimental or Artisanal Fishery data from Passive Gears. An Introductory Manual. Bergen: University of Bergen, Department of Fisheries and Marine Biology.

Kuster, C., Vuki, V. C., and Zann, L. P. (2005). Long-term trends in subsistence fishing patterns and coral reef fisheries yield from a remote Fijian island. Fish. Res. 76, 221-228. doi: 10.1016/j.fishres.2005. 06.011

López-Angarita, J., Hunnam, K. J., Pereira, M., Mills, D. J., Pant, J., Teoh, S. J., et al. (2019). Fisheries and Aquaculture of Timor-Leste in 2019: Current Knowledge and Opportunities. Penang: WorldFish. 
López-Angarita, J., Tilley, A., Díaz, J. M., Hawkins, J. P., Cagua, E. F., and Roberts, C. M. (2018). Winners and losers in area-based management of a small-scale fishery in the colombian pacific. Front. Mar. Sci. 5:23. doi: 10.3389/fmars.2018. 00023

Macfadyen, G., Huntington, T., and Cappell, R. (2009). Abandoned, Lost or Otherwise Discarded Fishing Gear. Rome: Food and Agriculture Organization of the United Nations.

Matsumoto, W. M., Kazama, T. K., and Aasted, D. C. (1981). Anchored fish aggregating devices in Hawaiian waters. Mar. Fish. Rev. 43, 1-13.

Maunder, M., Sibert, J., Fonteneau, A., Hampton, J., Kleiber, P., and Harley, S. (2006). Interpreting catch per unit effort data to assess the status of individual stocks and communities. ICES J. Mar. Sci. 63, 1373-1385. doi: 10.1016/j. icesjms.2006.05.008

Maunder, M. N., and Punt, A. E. (2004). Standardizing catch and effort data: a review of recent approaches. Fish. Res. 70, 141-159. doi: 10.1016/j.fishres.2004. 08.002

Maypa, A. P., Russ, G. R., Alcala, A. C., and Calumpong, H. P. (2002). Long-term trends in yield and catch rates of the coral reef fishery at Apo Island, central Philippines. Mar. Freshw. Res. 53, 207-213.

Mills, D. J., Abernethy, K. A., King, J., Hoddy, E. T., Teoh, S. J., Larocca, P., et al. (2013). Developing Timor-Leste's Coastal Economy: Assessing Potential Climate Change Impacts and Adaptation Options. Penang: WorldFish.

Mills, D. J., and Tilley, A. (2017). Exploring Opportunities to Improving Coastal Livelihoods and Resource Management in Timor-Leste's Coastal Communities. Canberra, ACT: ACIAR.

Mills, D. J., Tilley, A., Pereira, M., Hellebrandt, D., Pereira Fernandes, A., and Cohen, P. J. (2017). Livelihood diversity and dynamism in Timor-Leste; insights for coastal resource governance and livelihood development. Mar. Policy 82, 206-215. doi: 10.1016/j.marpol.2017. 04.021

Mora, C., Aburto-Oropeza, O., Ayala-Bocos, A., Ayotte, P. M., Banks, S., Bauman, A. G., et al. (2011). Global human footprint on the linkage between biodiversity and ecosystem functioning in reef fishes. PLoS Biol. 9:e1000606. doi: 10.1371/ journal.pbio.1000606

Oksanen, J., Blanchet, F. G., Friendly, M., Kindt, R., Legendre, P., McGlinn, D., et al. (2018). vegan: Community Ecology Package. R Package Version.

Ostrom, E. (1990). Governing the Commons: The Evolution of Institutions for Collective Action. Cambridge: Cambridge University Press.

Pandolfi, J. M. (2003). Global trajectories of the Long-Term decline of coral reef ecosystems. Science 301, 955-958. doi: 10.1126/science.108 5706
Peter, H. K., and van Zwieten, P. A. M. (2018). Operational, environmental, and resource productivity factors driving spatial distribution of gillnet and longline fishers targeting Nile-perch (Lates niloticus), Lake Victoria. J. Great Lakes Res. 44, 1235-1251. doi: 10.1016/j.jglr.2018.10.010

R Core Team, (2018). R: A Language and Environment for Statistical Computing. Vienna: R Foundation for Statistical Computing.

Sainsbury, N. C., Genner, M. J., Saville, G. R., Pinnegar, J. K., O’Neill, C. K., Simpson, S. D., et al. (2018). Changing storminess and global capture fisheries. Nat. Clim. Chang. 8, 655-659. doi: 10.1038/s41558-018-0206-x

Sharp, M. (2011). The benefits of fish aggregating devices in the Pacific. SPC Fish. Newsl. 135, 28-36.

Sharp, M. (2012). Investment profile for anchored nearshore fish aggregating device. SPC Fish. Newsl. 136:46.

Sims, N. (1988). A Cost-Benefit Analysis of FADs in the Artisanal tuna Fishery in Raratonga. Noumea: South Pacific Commission.

Teh, L. S. L., Teh, L. C. L., and Sumaila, U. R. (2013). A global estimate of the number of coral reef fishers. PLoS One 8:e65397. doi: 10.1371/journal.pone. 0065397

Tilley, A., Hunnam, K., Mills, D., Steenbergen, D., Govan, H., Alonso-Poblacion, E., et al. (2019). Evaluating the fit of co-management for small-scale fisheries governance in Timor-Leste. Front. Mar. Sci. 6:392. doi: 10.3389/fmars.2019. 00392

Tsujimura, T. N., Alonso, E., Amaral, L., and Rodrigues, P. (2012). Safety at Sea Assessment in the Timor-Leste Small-Scale Fisheries Sector. Technical Report. Bangkok: Regional Fisheries Livelihoods Programme for South and Southeast Asia (GCP/RAS/237/SPA), doi: 10.13140/RG.2.2.35185.28004

von Grebmer, J., Bernstein, L., Hammond, F., Patterson, A., Sonntag, L., Klaus, J., et al. (2018). Global Hunger Index: Forced Migration and Hunger. Bonn: Welthungerhilfe and Concern Worldwide.

Conflict of Interest Statement: The authors declare that the research was conducted in the absence of any commercial or financial relationships that could be construed as a potential conflict of interest.

Copyright (c) 2019 Tilley, Wilkinson, Kolding, López-Angarita, Pereira and Mills. This is an open-access article distributed under the terms of the Creative Commons Attribution License (CC BY). The use, distribution or reproduction in other forums is permitted, provided the original author(s) and the copyright owner(s) are credited and that the original publication in this journal is cited, in accordance with accepted academic practice. No use, distribution or reproduction is permitted which does not comply with these terms. 